\title{
Felsic melts differentiating to more mafic compositions through crystal uptake: a case of felsic parental arc magmas for mafic lava flows at Taranaki volcano, New Zealand
}

\author{
NESSA GRACE D'MELLO ${ }^{1}$, GEORG ZELLMER ${ }^{2}$, TERESA \\ UBIDE $^{3}$, JOHN CAULFIELD ${ }^{4}$, RAIMUNDO BRAHM ${ }^{2}$, \\ JONATHAN PROCTER ${ }^{2}$, GABOR KERESZTURI ${ }^{2}$ AND \\ ROBERT STEWART ${ }^{2}$ \\ ${ }^{1}$ Massey University (Turitea) \\ ${ }^{2}$ Massey University \\ ${ }^{3}$ The University of Queensland \\ ${ }^{4}$ Queensland University of Technology \\ Presenting Author: n.dmello@massey.ac.nz
}

The prevalence of antecrystic minerals carried in porphyritic lava domes extruded from arc volcanoes are widely accepted, but less is known about the origins of crystals in more fluid lava flows. The crystal cargo of the Holocene Taranaki lava flows is dominated by plagioclase, clinopyroxene and amphibole exhibiting complex textural features and chemical zonations that are indicative of varied growth and resorption histories. Mineral chemistry of these phases reveals a chemical disequilibrium with the melt they are entrained in, and an overlap of major and trace element compositional data from xenoliths in Taranaki. The suite of xenoliths includes ultramafic rocks, gabbros and amphibolites and remain fairly constant in composition throughout the history of the volcano. Further, the ratio of the crystals entrained in the lavas, ranging between $35-60 \%$, exerts a primary control on the whole rock composition of the lavas, displaying a wide array of compositions from basalts to trachyandesites. The ascent pathway of high-temperature, aphyric melts of intermediate composition through a colder, more mafic mush zone determines the mineral phases and their proportions observed in the lavas and in consequence, the composition of the eruptives. Our data are inconsistent with commonly invoked processes of fractional crystallization and concomitant evolution to more felsic composition. Instead, the most "differentiated" lavas are the most mafic due to subvolcanic crystal uptake, while the most felsic most closely resemble aphyric to sparsely phyric parental melt compositions reaching the upper crustal mush zone beneath the volcano, represented by the groundmass. This implies that some primary melts from the mantle wedge behind the Hikurangi margin may be more felsic than the typical primary arc basalts that are commonly invoked. 